\title{
nature
}

\section{Can Hong Kong avoid a future of decline?}

\section{As it nears the transfer of its governance to China, Hong Kong is hampered by the consequences of historical short-sightedness. Its technological future depends on substantial investment and continuing freedoms.}

$\mathrm{N}$ obody knows for certain what it's going to be like in Hong Kong over the next few years, but pessimists point to two alternative ways in which the 'special administrative region', as it will be known after its handover to China on 30 June, could tumble from its estimable position at eighth in the ranking of trading nations. The least sad of the two pessimistic scenarios is that Hong Kong becomes the Monaco of East Asia - a pleasure garden tolerated as such by the mainland government, its economy based on trade brokering, property and financial speculation, with the dubious charm of a glitzy European monarchy replaced by an altogether weightier executive backed by the Chinese army.

An even worse alternative is that China loses the will to sustain its much vaunted 'one country, two systems' policy for the territory, stamps out freedom of expression and causes the abandonment of the region, and of its six million Chinese inhabitants, by the world's investors. Few inhabitants give this future much credence. China has too much to lose, goes the argument - both in Hong Kong and in Taiwan, whose reintegration with the mainland is very close to China's heart and for which Hong Kong's new administrative arrangements are seen as a prototype.

With such dire possibilities in mind, those more ambitious for the region might well settle for a continuation of the present - an energetic trading post with low-technology manufacturing dependent increasingly on mainland labour, and a gateway to and from expanding mainland markets. But with China depending less and less on it for its traffic with other countries, Hong Kong has to reposition itself. East Asia has other examples of relatively small economies that have embraced high technology to carve themselves a niche. Can Hong Kong sensibly develop in that direction?

Some of the territory's academics appear to believe so. Certainly it would be hard for it to spend less on research and development than the present fraction of a per cent of gross domestic product. In that negative sense, there is plenty of room for growth. If other East Asian countries are a guide, the laissez-faire approach of past executives can be expected to change under the new administration. New tax incentives are likely, to encourage traditional as well as recently founded small high-technology companies to fulfil their potential, while the growth in government funds for university research and development (R\&D) may be boosted further, and a nascent science park may be launched - first as a virtual entity, then as a physical development.

Such possibilities can be made to sound positively glowing. Nevertheless, a scrutiny of the territory's science base is sobering. Of the handful of universities, three could claim to have a substantial and internationally competitive research capacity: the venerable Hong Kong University, the Chinese University of Hong Kong and the 'young turk' of the bunch, Hong Kong University of Science and Technology. All three face challenges unique to Hong Kong.

First, one should recall that the striking growth in science and technology in East Asia's tigers has been accomplished with the indispensable help of Chinese returning from the West, especially from the United States. The development of science in Taiwan, South Korea and even China has depended on such people filling key posts, both in research institutions and elsewhere. Hong Kong is superficially attractive to such people because, by the region's standards, it pays well, and has been recruiting at a time when the West has been a poor source of employment. But whether it can recruit people of the highest calibre and then retain them is another question. There has been some capital investment in new laboratories in recent years, but the total recurrent expenditure on university research over the past decade would not maintain a major US university for a year.

A second profound challenge relates to the territory's education system. One aspect here is the declining linguistic flexibility of the young. English is meant to be widely spoken within schools and universities, but isn't - and other countries with international attractiveness in mind achieve better performance in English amongst the population. Furthermore, the majority of Hong Kong's inhabitants speak Cantonese rather than the putonghua (Mandarin) Chinese common elsewhere. Another worry is cultural: as on the mainland, young Chinese emerge from high school with a depressing lack of inclination to question received ideas. That does not limit their flair as entrepreneurs, but it undermines the potential for flourishing science.

A third millstone is history. Hong Kong is already well on the way to casting off cultural and administrative impediments from its colonial past, but it has flourished economically on business shorttermism and the pursuit of rapid personal gain. There cannot be many countries that decide, as Hong Kong's executive did as recently as 1983 , that research was not to be encouraged in universities and that companies should be left entirely free of a regional strategy in R\&D. As a result, Hong Kong now has a depleted proportion of technology-based industries, and a university science research base and infrastructure that is less than ten years old.

Given the wealth of the territory; and the acknowledgement by the new chief executive Tung Chee-Hwa that technology growth and $\mathrm{R} \& \mathrm{D}$ are important factors for its future, Hong Kong's academics have a great deal to play for. But much depends on the new administration, and the mainland government behind it. The latter's attitude to Hong Kong will no doubt be regrettably tempered by a fear of its potentially liberalizing influence on its population, but also by its urgent need to boost the livelihood of China, where poverty is endemic and widespread.

It is to be hoped that China's rulers will be persuaded that Hong Kong merits immediate and long-term science and technological investment. But if that strategy is to have a chance of succeeding, they will need to keep several goals uppermost in mind, over and above the deployment of more of the territory's resources in education, science and engineering: the positive development of independent thinking and expression in academic institutions, continued open access to the international flow of people and ideas, and the avoidance of cronyism at the expense of merit in appointments. Only thus can Hong Kong avoid a future of intellectual and technological decline. 